\title{
The Advertisement of Sampoerna Hijau Cigarette Kondangan Edition Semiotic Reviews by Roland Barthes
}

\author{
Dina Rizki Triana, Universitas Airlangga \\ Nadiyatul Adabiyyah, Universitas Airlangga
}

\begin{abstract}
Each sign has a hidden meaning and meaning to be communicated to others in order that communication process functions properly. One example is the advertising media on television. Ads basically uses a persuasive sentence that aims to invite consumers to buy the products. The purpose of the research is to describe the denotative and connotative meaning of the message contained in the cigarette advertisement Sampoerna Hijau Kondangan edition. The reason for the selection of Sampoerna Hijau cigarettes is because the advertisements displayed contain unique meaning. The contents of the video show three people coming to the wedding invitation, then choose a green chicken that is the identity of cigarettes Sampoerna. Chicken with red and yellow colors referring to other cigarettes are illustrated not favorably on the ads. The data of Ads video was taken from YouTube. The method used is listening and taking note techniques by observing the data that appears in every scene. Qualitative descriptive is used to analyze the data. The theory used is Roland Barthes Semiotics, including markers, and connotative signs. The result shows that cigarette ads of Sampoerna Hijau Kondangan edition has semiotic signs and messages that show a reflection of smokers. The expression and the slogan Nikmatnya Rame-Rame shows that the cigarettes are delicious when consumed together.
\end{abstract}

Keywords: advertisement; Sampoerna hijau cigarette kondangan edition; semotics by Roland Barthes; society

\section{Introduction}

Sign is defined as a representation of a phenomenon that has a number of gifts, such as names, roles, functions, objectives, and meanings. These marks are found throughout human life, thus becoming the intrinsic value of every human culture and becoming a sign system used as a regulator of life (Rusmana , 2014). Each sign has a hidden meaning and meaning to be conveyed to others. by understanding the meaning conveyed from the sign we can make our communication process or message run well. The message conveyed can be a belief, idea, or thought of the sign maker. Semiotics is a science that studies the signs in society, showing the shape of the sign and the rules managing it.

Signs that indicate the existence of a process of communication one of which is the advertising media shown on television. Ads basically uses a persuasive sentence that aims to invite consumers to buy the product. In the marketing process ads often uses the sign system in audio visual form to represent the product. The signs are a combination of images, colors, or text that refer to the object.

Advertisement has a sign system in the form of uncommon message often aimed at criticizing something that still has relation to the marketed product. The critiques can be social, economical, political, or cultural critiques. Just as in the cigarette advertisement of Sampoerna Hijau, there is a sign system that not only aims to market the product, but also to convey a hidden meaning in the form of ideas to the consumers. The signs contained in the ads depict the social scope of the smokers. The advertisement does not directly describe the cigarette itself, but it is packed with a system of signs that are still related to the community. The audience is served by the advertiser on a thought about smokers reflected in the video which then refers to the quality of the product.

Signs as a system used in literary works may have various perceptions that explain an object, illustrate an event and explain the use of the system that applies as an icon. In all of the time there must be signs that humans decided to use and surely there must something they acknowledge as a means for other things (Eco, 2009). 
This study uses listening and taking note techniques by observing the data that appears in every scene that appear in the video. Qualitative descriptive is used to analyze the data. It studied and analyzed all previously collected data to describe Sampoena Hijau Cigarette advertisement Kondangan edition using Semiotic of Roland Barthes. The purpose of descriptive analysis is to understand the implied message by giving a systematic, factual, and accurate description, or illustration of the facts contained in the video.

\section{Discussion}

Barthes (in Rusmana, 2014: 185) mentions the process of interpreting sign with signification is the process of placing a sign with a sign that then produces a sign. Barthes develops the concept of connotative meaning and not just stop at the primary meaning (denotative). Denotative meaning is the meaning of the sign that refers to the explicit meaning, which is the actual meaning. Whereas connotative meaning is a meaning that refers to the implicit meaning, i.e., meaning that is not real or hidden meaning.

The denotative meaning (often also called denotational meaning, conceptual meaning, or cognitive meaning as seen from another perspective) is essentially the same as the referential meaning because this denotative meaning commonly gives explanation as meaning in accordance with the observation result according to sight, smell, hearing, feeling, or experience. Thus, this denotative meaning involves objective factual information (Chaer, 2009).

\section{Scene 1}

$\begin{aligned} & \text { Signifier } \\ & \text { Three men looked at the various chicken } \\ & \text { menus and they were tempted }\end{aligned}$
$\begin{aligned} & \text { The Men want to taste all the chicken } \\ & \text { available }\end{aligned}$
Three men who wanted to taste the three chicken menus
Connotative Signifier
There are three brands of cigarettes
available in front of the three men concept of advertising strategies that
strive to cause curiosity to consumers.


Scene 2

\begin{tabular}{|c|c|}
\hline $\begin{array}{l}\text { Signifier } \\
\text { The three men tasted the brown chicken }\end{array}$ & $\begin{array}{c}\text { Signified } \\
\text { Chicken flavor was bland, not tasty }\end{array}$ \\
\hline \multicolumn{2}{|c|}{ Denotative Sign } \\
\hline $\begin{array}{c}\text { Connotative Signifier } \\
\text { The cigarette is described as brown Djarum. }\end{array}$ & $\begin{array}{l}\text { Connotative Signified } \\
\text { Cigarettes other than green Sampoerna not } \\
\text { tasty, tasteless (showing less in qualities). }\end{array}$ \\
\hline \multicolumn{2}{|c|}{$\begin{array}{l}\text { Connotative Sign } \\
\text { The ads is in the form of satire (indirectly) and shows that it is as if only Sampoerna Hijau } \\
\text { cigarettes which is the best quality of all. In reality in the scope of the entertainment world } \\
\text { advertising an item by turning off another product is one of the marketing strategies that } \\
\text { actually cause misunderstandings. Indirectly these satires can also contain violence in the } \\
\text { case of defamation of a product that can cause a sense of unhealthy competition between one } \\
\text { party to another. }\end{array}$} \\
\hline
\end{tabular}

Scene 3

Signifier

Signified

Three people who came to the invitation tried The concept of people who like to try. the red spice chicken dish.

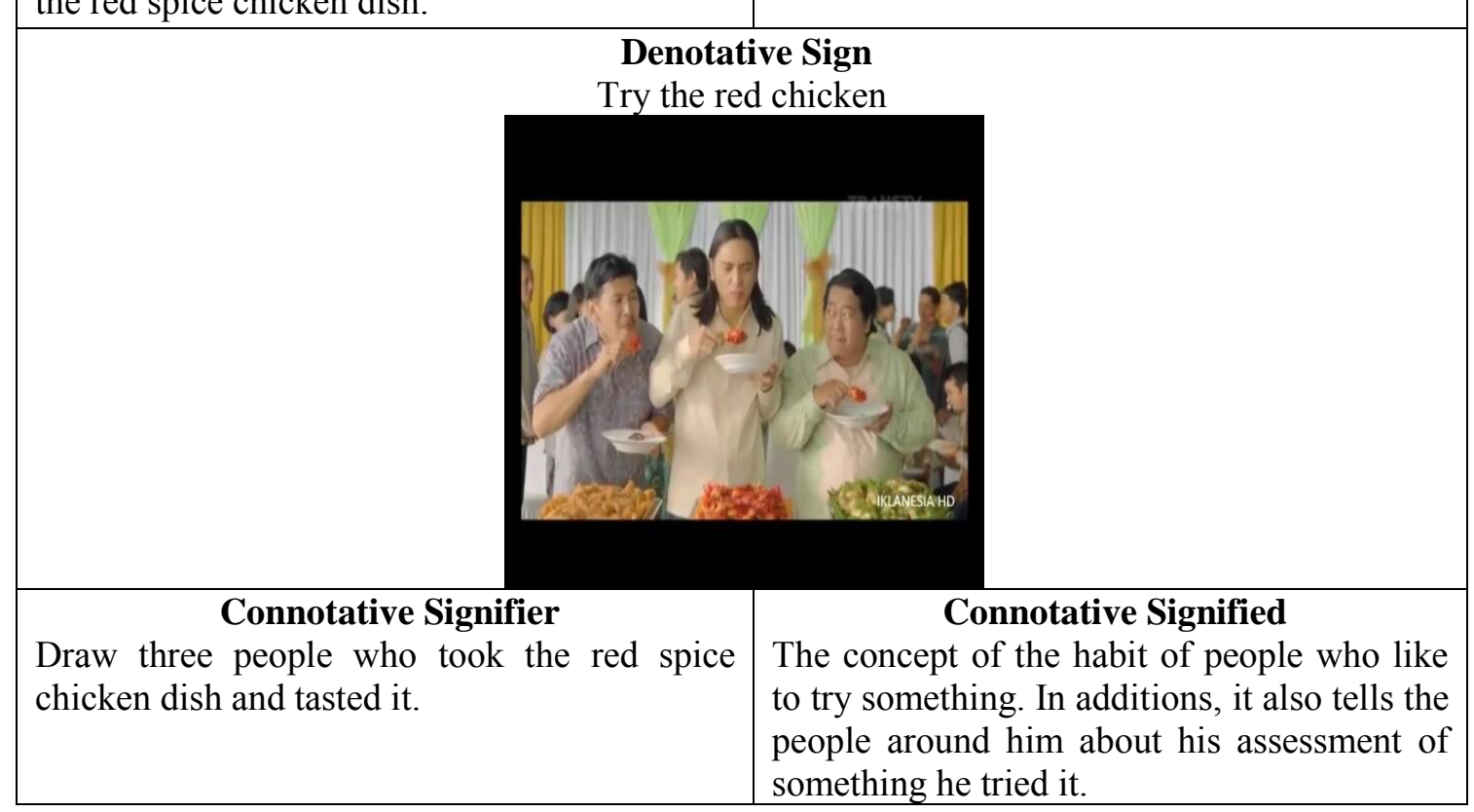


Scene 3, cont.

\section{Connotative Sign}

Culture of Indonesian people who are interested in the variations that exist. In addition, the community also seeks to find the right fit with his wish by trying the variations that exist one by one. After trying the variations that exist, they make judgments and will tell people nearby like friends, relatives, neighbors, and others.

\section{Scene 4}

\begin{tabular}{|c|c|}
\hline $\begin{array}{l}\text { Signifier } \\
\text { Three people who smelled the last chicken } \\
\text { dish that is spicy chicken chili. }\end{array}$ & $\begin{array}{l}\text { Signified } \\
\text { The concept of society that finds something } \\
\text { to their liking. }\end{array}$ \\
\hline \multicolumn{2}{|c|}{$\begin{array}{l}\text { Denotative Sign } \\
\mathrm{n} \text { will taste the green chicken }\end{array}$} \\
\hline $\begin{array}{l}\text { Connotative Signifier } \\
\text { Picture of three people who inhale the smell } \\
\text { of green chicken dish with some expressions } \\
\text { want to eat the dish. }\end{array}$ & $\begin{array}{l}\text { Connotative Signified } \\
\text { The concept of a society that finds } \\
\text { something tasty and appropriate to their } \\
\text { tastes, in this case is green chicken dish, } \\
\text { which is expressed with several expressions } \\
\text { of each. }\end{array}$ \\
\hline \multicolumn{2}{|c|}{$\begin{array}{l}\text { Connotative Sign } \\
\text { oresses what they feel about what they think is good and } \\
\text { erently. }\end{array}$} \\
\hline
\end{tabular}

Scene 5

Some people are starting to take food in the The concept of consumers who have chosen form of chicken flavored with green chili. Sampoerna hijau product; green color is a sign (characteristics) of the product.

\begin{tabular}{|l|l|}
\hline $\begin{array}{c}\text { Denotative Sign } \\
\text { Dishes selected by the three men }\end{array}$ & $\begin{array}{c}\text { Connotative Signified } \\
\text { The concept of consumer's choice that } \\
\text { believes that Sampoerna Hijau cigarette has } \\
\text { good quality, so it is worth to be chosen. }\end{array}$ \\
\hline \\
Referring to the freedom of consumers' right to choose the tobacco products they want to \\
buy. The choice of consumers is in fact still heavily influenced by the thoughts and \\
assumptions of others. So, people are made to think repeatedly when deciding a choice.
\end{tabular}




\section{Conclusion}

In Sampoerna Hijau cigarette advertisement, there are a number of sign systems aimed not only as marketing strategy, but also as a way of presenting some thoughts about smokers related to a particular culture. The sign system is examined based on Roland Barthes's theory of connotative and denotative marks. In the cigarette advertisement was found the reflections of smokers, color symbols, expression shapes, and the sign of the fun of rame-rame affirming patterns that reflect the quality of the product. Communities or consumers are served with a form of advertising that indirectly provide suggestions that are packaged with marketing strategies by providing a form of reflection.

\section{References}

Barthes, R. 2010. Membedah mitos-mitos budayam: Semiotika atau sosiologi tanda, simbol, dan reresentasi.Yogyakarta: Jalasutra.

Chaer, A. 2009. Pengantar semantik Bahasa Indonesia. Jakarta: Rineka Cipta.

Danesi, M. 2010. Pengantar memahami semiotika media. Yogyakarta: Jalasutra.

Eco, U. 2009. Teori semiotika: Signifikasi komunikasi, teori kode, serta teori produksi tanda. Yogyakarta: Kreasi Wacana.

Hanafi, A. 1984. Memahami komunikasi antar manusia. Surabaya: Usaha Nasional.

Halliday, M.A.K \& Ruqaiya, H. 1992. Bahasa, konteks, dan teks: Aspek-aspek bahasa dalam pandangan semiotik sosial. Yogyakarta: Gadjah Mada University Press.

Rusmana, D. 2014. Filsafat semiotika: Paradigma, teori, dan metode interpretasi tanda dari semiotika struktural hingga dekonstruksi praktis. Bandung: Pustaka Setia. 